\title{
The European barley powdery mildew virulence survey and disease nursery 1993-1999
}

\author{
Mogens S. Hovmøller ${ }^{a *}$, Valérie CAFFier ${ }^{\mathrm{b}}$, Marja JALli ${ }^{\mathrm{c}}$, Ole Andersen**, \\ Gottfried Besenhofer**, Jerzy H. CZEMBor**, Antonin Dreiseitl**, \\ Friedrich Felsenstein**, Andreas FlecK**, Fritz HeInRICS**, Rickard Jonsson**, \\ Eckhard LIMPERT**, Peter MERCER**, Svetozar PLESNIK**, Isaak RASHAL**, \\ Helge SKInNeS**, Susan Slater**, Olga VRONSKA** \\ ${ }^{\text {a }}$ Danish Institute of Agricultural Sciences, Research Centre Flakkebjerg, 4200 Slagelse, Denmark \\ ${ }^{\mathrm{b}}$ Station of Plant Pathology, INRA, BP 57, 49071 Beaucouzé Cedex, France \\ ${ }^{\mathrm{c}}$ Boreal Plant Breeding Ltd., Myllytie 10, 31600 Jokioinen, Finland
}

(Received 10 May 2000; revised 5 July 2000; accepted 3 August 2000)

\begin{abstract}
National barley powdery mildew virulence surveys were co-ordinated through COST817 on a European scale from 1993 to 1999 to allow comparison of results across national borders. The frequencies of virulence matching resistance genes Mla1, Mla3, Mla6, Mla7, Mla9, Mla12, Mla13, Mlk, MlLa and Mlg were moderate to high in most years and countries. Several additional sources of resistance were matched by virulence frequencies below 5\%. Generally, no increase in aggressiveness against Mlo-resistance was detected, but change may be under way as particular isolates of British origin gave higher infection levels on Mlo-resistant varieties than did other groups of isolates. Therefore, it is important in the future to focus on virulence matching the new sources of resistance and Mlo. Multi-location field trials were established in 1998 and 1999 in order to study powdery mildew resistance in barley genotypes in different environments. The trials showed large interactions of location and phenotypic expression of the resistance. A continued exchange of ideas, methodology and plant material between national survey programmes, and a rapid dissemination of results to farmers and plant breeders across Europe is vital.
\end{abstract}

Erysiphe graminis f. sp. hordei / virulence survey / disease nursery / partial resistance / blumeria graminis f. sp. hordei

Communicated by Hanne Østergård (Roskilde, Denmark)

* Correspondence and reprints

Mogens.Hovmoller@agrsci.dk

** Affiliations are in Appendix. 
Résumé - Étude des virulences dans les populations d'oïdium de l'orge et évaluation des variétés pour leurs résistances partielles à l'échelle européenne de 1993 à 1999. Les suivis nationaux de virulences chez l'oïdium de l'orge ont été coordonnés à l'échelle européenne de 1993 à 1999 dans le cadre de l'action COST817. L'objectif était de comparer les résultats au-delà des frontières nationales. Les fréquences de virulences correspondant aux gènes de résistance Mla1, Mla3, Mla6, Mla7, Mla9, Mla12, Mla13, Mlk, MlLa et Mlg étaient modérées à fortes pour la plupart des années et des pays. Pour plusieurs sources de résistance supplémentaires, les fréquences de virulences étaient inférieures à $5 \%$. En général, aucune augmentation d'agressivité vis-à-vis de la résistance Mlo n'a été détectée, mais des changements pourraient être en cours puisque des isolats particuliers d'origine britannique inoculés sur des variétés possédant la résistance Mlo ont présenté des niveaux d'infection plus élevés que d'autres groupes d'isolats. Par conséquent, il est important dans le futur d'étudier avec attention les virulences correspondant aux nouvelles sources de résistance et à la résistance Mlo. Des essais au champ multilocaux ont été mis en place en 1998 et 1999 pour étudier la résistance à l'oïdium des génotypes d'orge dans différents environnements. Ces essais ont montré de grandes interactions entre lieu et expression phénotypique de la résistance. Il est primordial de poursuivre les échanges d'idées, de méthodologie et de matériel végétal entre programmes de suivis nationaux, et de distribuer rapidement les résultats aux agriculteurs et aux sélectionneurs à travers l'Europe.

Erysiphe graminis f. sp. hordei / suivi européen / virulence / résistance partielle / Blumeria graminis f. sp. hordei

\section{Introduction}

The use of host resistance to control barley powdery mildew, caused by the fungus Blumeria (Erysiphe) graminis f. sp. hordei, is widely recommended because it is environmentally safe and comes with the seed at no extra cost to the farmer. However, the use of the same resistance genes across wide areas leads to selection in favour of pathotypes with the matching virulence genes in the pathogen population $[1,5,21,31,50]$. This may result in previously resistant varieties becoming susceptible, often referred to as the 'breakdown' of resistance.

For more than fifty years, barley powdery mildew 'race-surveys' [e.g. 17, 37, 49] and later national 'virulence surveys' have been carried out throughout Europe [e.g. 1, 11, 14, 18, 24, 34, 40, $45,47,48,53]$. The surveys in the different countries often have slightly different objectives, and therefore use different sampling strategies and test methods. Nevertheless, most surveys have a common aim of monitoring changes in frequencies of pathotypes (or single genes) of relevance for resistance breeding and plant production. Surveys may also provide the basis for variety diversification schemes [45] and can be used in giving advice on disease risk and fungicide management [13].
Finally, survey data may be used to study the dynamics of the pathogen population on a regional or international scale $[6,9,30,52]$.

When a particular source of resistance has been overcome by the pathogen population in one area, varieties possessing the same resistance are at risk in neighbouring areas. This is mainly because the pathogen is easily spread by airborne spores, often not very far from the plant on which they were produced but under optimal conditions up to several hundred $\mathrm{km}$, from one country to the other [16].

To ensure sufficient powdery mildew control by the use of host resistance, new sources of resistance should currently be entering breeding programmes, e.g. resistance genes from wild relatives of barley [25, 44]. Another strategy is to increase the general level of resistance to powdery mildew in the barley germ plasm [27]. Such resistance, denoted 'partial resistance', is not based on single genes with a major effect, and it has been subject to much interest because it is often considered to remain effective for a longer time than race-specific resistance genes [39]. Partial resistance is often expressed in adult plants, and the efficiency depends much on environment [36]. Under field conditions, partial resistance is expressed by a slow powdery mildew development, and under laboratory conditions, partial resistance can be assessed by 
parameters influencing infection frequency, latent period and/or sporulation capacity [26]. The formation of papillae is one major component of partial resistance [15]. As the efficiency of partial resistance depends on environment it is preferable to make the tests at various sites, e.g. to expose the material to different pathogen populations.

Within COST817, national virulence surveys and evaluation of varieties for partial resistance were co-ordinated on a European scale. In the present paper, the authors present changes and differences in virulence gene frequencies in a pathogen population consisting of airborne spores sampled across wide geographical areas for several successive years. Examples of different virulence survey approaches in different European countries are shown, and the usefulness of the different type of results obtained is discussed. The paper also describes results from multinational barley powdery mildew field nurseries, aimed at identifying promising sources of partial resistance in the barley germplasm. The success of such work depends to a large extent on knowledge of the virulence distribution in the local pathogen population.

\section{Materials and methods}

\subsection{Virulence surveys}

The barley powdery mildew virulence surveys have two main aspects, sampling and virulence testing. There have been different approaches to sampling, viz. use of trap plants in barley fields or at a location distant from barley crops [22]; mobile spore traps attached to a car roof and which collect spores by exposing susceptible plants while driving $[30,41]$; collection of isolates from leaf samples from barley crops [45]. Thus, sampling was not always carried out on a strictly random basis, but aimed to collect the most relevant information for the purpose of the survey (Tab. I). Samples of random airborne powdery mildew spores in most countries were collected during summer when both autumn sown barley and spring sown barley were present (Tab. I). In most countries, single colonies were collected on varieties that were susceptible to the current powdery mildew population. In some countries, additional samples were collected on varieties with Mlo-resistance.

The virulence testing was generally carried out by inoculating detached leaf segments of differential lines or varieties placed on agar containing benzimidazole. The differential lines were chosen to have different resistance genes (Tab. II). Some of them have been extensively used in European varieties [7] whereas others have been included only recently in breeding programmes and are not yet widely used by growers. When available, near isogenic lines of Pallas [28] were used. After 7 to 8 days of incubation (e.g. $16{ }^{\circ} \mathrm{C}$, continuous light, $10 \mu \mathrm{E} \cdot \mathrm{s}^{-1} \cdot \mathrm{m}^{-2}$ ), the infection types (IT) were scored on a $0-4$ scale [35]. Isolates were classified as avirulent (ITs $0-3$ ) or virulent (IT 4) on the varieties used; in specific cases, the infection types were interpreted genetically, indicating the presence of specific avirulence and virulence alleles [22].

'Early' detection of pathotypes matching new sources of resistance was carried out through a detailed screening of resistant varieties in naturally infected disease nursery plots (Denmark) [18]. Sampling of colonies/lesions took place when their presence was first reported on a certain variety/breeding line, often in May-June (summer). Potential colonies were further multiplied and inoculated on an extended differential set (Tab. II), and sometimes further tested on commercial varieties/breeding lines. Additional tests for increased virulence/aggressiveness on Mlo-resistant varieties were generally done by counting colonies on trap plants of such varieties in comparison to susceptible control plants. Selected isolates were further investigated by the procedure developed by Lyngkjær et al. [33] (Denmark only) or by repeated tests using seedlings of a larger range of Mlo-resistant varieties (UK only).

\subsection{Disease nurseries}

In 1998 and 1999, spring barley nurseries were sown in up to seven European countries, i.e. 
Table I. Sampling details for the barley powdery mildew virulence survey in Europe.

\begin{tabular}{|c|c|c|c|c|}
\hline \multirow[t]{2}{*}{ Country } & \multicolumn{3}{|c|}{ Sampling details } & \multirow[b]{2}{*}{ Local contact person } \\
\hline & Season & Trap plant exposure & Trap plant variety & \\
\hline Austria (AT) & Summer & Mobile spore trap & Dvoran & S. Plesnik; G. Besenhofer \\
\hline Czech Republic (CZ) & Summer & Mobile spore trap & Pallas & A. Dreiseitl \\
\hline Germany (DE) & Summer & $\begin{array}{l}\text { Mobile spore trap } \\
\text { and in fields }\end{array}$ & Igri, Pastoral & F. Felsenstein, K. Flath \\
\hline Denmark (DK) & Winter & Stationary (remote) & Igri, Apex, Alexis & MS. Hovmoller \\
\hline Finland (FI) & Summer & Fields* & Golden Promise & M. Jalli \\
\hline France (FR) & Winter & Mobile spore trap & Igri & V. Caffier, L. Bousset \\
\hline Hungary (HU) & Summer & Mobile spore trap & Dvoran & S. Plesnik \\
\hline N. Ireland (NI) & Summer & Fields & Golden Promise & P. Mercer, A. Ruddock \\
\hline Latvia (LV) & Summer & Fields & Otra & I. Rashal, I. Kokina, I. Araja \\
\hline Poland (PL) & Summer & Fields & Manchuria & $\begin{array}{l}\text { J.H. Czembor, E. Gacek, R. Bilinski; } \\
\text { H.J. Czembor }\end{array}$ \\
\hline Slovakia (SK) & Summer & Mobile spore trap & Dvoran & S. Plesnik, E. Krippel, M. Sykora \\
\hline Ukraine (UA) & Summer & In fields* & $?$ & O. Vronska, G. Kosilovich \\
\hline Great Britain (GB) & $\begin{array}{l}\text { Winter and } \\
\text { summer }\end{array}$ & $\begin{array}{l}\text { Stationary (remote) and } \\
\text { from infected leaves }\end{array}$ & $\begin{array}{l}\text { Golden Promise, } \\
\text { Apex, Riviera }\end{array}$ & S. Slater, J.D.S. Clarkson \\
\hline
\end{tabular}

* or from infected leaves.

Austria, Denmark (two sites in 1998), Finland, Germany, Latvia, Norway and Sweden. Altogether, 36 varieties and breeding lines were investigated, and 16 were tested at all sites in both years. The seed was sown in fields in $2-4$ replicates using small plots or hill plots. The level of powdery mildew was assessed as an average score for each small plot, based on natural powdery mildew infection. The assessments were carried out 2-3 times at each location and year, where the following scale (either expressed as a figure between 0 and 9 or in percent) was used: 0: no powdery mildew symptoms in the plot, $1(=0.1 \%$ leaf area covered): less than one colony/plant, $2(=0.5 \%)$ : approximately three colonies/tiller, $3(=1 \%)$ : approximately five colonies/leaf, $4(=5 \%)$ : two lower leaves approximately $25 \%$ covered by powdery mildew, 5 $(=10 \%)$ : two lower leaves approximately $50 \%$ covered by powdery mildew, $6(=25 \%)$ : half of the leaf area appear to be diseased, $7(=50 \%)$ : leaves appeared more diseased than green, $8(=75 \%)$ : very little green tissus left, $9(=100 \%)$ : all leaves dead. In 1999, a set of Pallas near-isogenic lines (cf. Tab. II) was sown together with disease nurs- eries in Austria, Denmark, Finland and Sweden in order to obtain a local estimate of the virulence spectrum.

\section{Results and discussion}

\subsection{Barley powdery mildew virulence surveys in Europe}

In the following, examples of different approaches to virulence surveys in Europe are described.

\subsubsection{Early detection of 'new' virulence}

One purpose of virulence surveys is to observe the very first indication of a 'break down' of newly utilised resistance genes, e.g. a change in virulence frequency from 0 to $1 \%$ in the aerial population. Table III presents an example of the evolution of virulence matching the resistance in recently released barley varieties in Denmark. Virulence was detected at least once for all varieties except 
Table II. Differential varieties used in the national virulence surveys and known powdery mildew resistance genes in these (country code ${ }^{\mathrm{a}}$ in parenthesis).

\begin{tabular}{|c|c|c|c|}
\hline No. & Pallas line [28] & Supplementary variety & Resistance gene(s) ${ }^{b}$ \\
\hline 1 & Pallas (DK) & & Mlas \\
\hline 2 & P01 (all except GB and NI) & Tyra (GB), Delta (NI) & Mlal, $\operatorname{Ml}(A l 2)$ \\
\hline 3 & P02 (all except GB and NI) & Ricardo (GB) & Mla3 \\
\hline 4 & P03 (all except GB and NI) & Midas (GB, NI) & Mla6, Mla14 \\
\hline 5 & P04B (all except GB and NI) & Porter (GB), Regina (GB) & $M l a 7, \operatorname{Ml}(N o 3)$ \\
\hline 6 & P08B (all except GB and NI) & Roland (GB), Leith (NI) & Mla9 \\
\hline 7 & P10 (all except GB and NI) & Hassan $(\mathrm{GB}, \mathrm{NI})$ & $\operatorname{Mla12}, \operatorname{Ml}(\operatorname{Em} 2)$ \\
\hline 8 & P11 (all except GB and NI) & Digger $(\mathrm{GB}, \mathrm{NI})$ & Mla13, Ml(Ru3) \\
\hline 9 & P16 (all except GB and NI) & Hordeum 1063 (GB), P17 (DE, LV) & Mlk \\
\hline 10 & P23 (all except GB and NI) & Lofa Abed (GB), Varunda (NI) & MlLa \\
\hline 11 & P09 (DK, FR, PL) & & Mla10, $M l(D u 2)$ \\
\hline 12 & P12 (DK, FI, FR, PL) & & Mla22 \\
\hline 13 & P13 (LV, PL) & & Mla23 \\
\hline 14 & P19 (LV, PL) & & $M l p$ \\
\hline 15 & P20 (CZ, DK, LV, PL) & & Mlat \\
\hline 16 & P21 (AT, DK, FR, HU, FI, PL) & Zephyr (GB, NI) & $M l g, M l(C P)$ \\
\hline 17 & P22 (LV, PL) & & mlo5 \\
\hline 18 & P24 (DK, FI, FR, LV, PL) & Weihenstephan 37/136 (GB) & Mlh \\
\hline 19 & & Gunnar (DK, PL) & Mla3, $\operatorname{Ml}(T u 2)$ \\
\hline 20 & & Punto (DK) & Mla3, Ml/Tu2), Ml(Im9), Ml(Hu4) \\
\hline 21 & & Goldspear (NI) & Mla6, MlLa \\
\hline 22 & & Triumph (AT, HU, PL, SK, GB NI) & $M l a 7, \operatorname{Ml}(A b)$ \\
\hline 23 & & $\operatorname{Keg}(\mathrm{NI})$ & Mla7, Mlk \\
\hline 24 & & Klaxon (NI) & Mla7, Mlk, MlLa \\
\hline 25 & & Hulda (DK) & Mla 7, Ml(Im9), Ml(Hu4) \\
\hline 26 & & Henni (DK) & Mla7, $U$ \\
\hline 27 & & Simon (GB) & Mla9, Mlk \\
\hline 28 & & Benedicte (DK, PL) & Mla9, Ml(Im9) \\
\hline 29 & & Egmont (NI) & Mla12, MlLa \\
\hline 30 & & Goldie (DK, FR, LV, SK) & Mla12,MlLa, $U$ \\
\hline 31 & & Tofta (DK) & $\operatorname{Mla13}, \operatorname{Ml}(\operatorname{Im} 9)$ \\
\hline 32 & & Meltan (DK, FR, LV, SK) & Mla13,Ml(Im9), Ml(Hu4) \\
\hline 33 & & Tyne (NI) & Mla13, MlLa \\
\hline 34 & & $\operatorname{Dram}(\mathrm{NI})$ & Mlk, MlLa \\
\hline 35 & & Apex $(\mathrm{DK}, \mathrm{GB})$ & mlol1 \\
\hline 36 & & SV83380 (DK), Lotta (GB) & $\operatorname{Ml}(A b)$ \\
\hline 37 & & Goldfoil (GB) & Mlg \\
\hline 38 & & Weihenstephan 41/145 (GB) & Mlra \\
\hline 39 & & Jarek (LV, PL) & $\operatorname{MlLa}, \operatorname{Ml}(K r)$ \\
\hline 40 & & Steffi (DK, FR, LV, PL, SK) & $M l(S t 1), M l(S t 2)$ \\
\hline 41 & & SI1 (DK, FR, LV, SK) & $\operatorname{Ml}(S I 1)$ \\
\hline 42 & & Optima (DK) & $U 1$ \\
\hline 43 & & Scarlett (DK) & $U 2$ \\
\hline
\end{tabular}

${ }^{a}$ AT Austria, CZ Czech Republic, DE Germany, DK Denmark, FI Finland, FR France, HU Hungary, NI N.Ireland, LV Latvia, PL Poland, SK Slovakia, UA Ukraine, GB Great Britain.

${ }^{\mathrm{b}}$ Designation according to [3]. 
Table III. Summary of virulence frequencies (\%) matching resistance in newly released varieties in Denmark.

\begin{tabular}{lccccccccccc}
\hline Year & \multirow{2}{*}{ No isolates } & \multicolumn{10}{c}{ Virulence frequencies (\%) } \\
\cline { 3 - 12 } & & Steffi & Henni & Benedicte & Goldie & Meltan & Optima & Scarlett & Gunnar & SI1 & Punto \\
\hline $1996 / 1997$ & 168 & $<1$ & - & 2 & 2 & 0 & - & - & $<1$ & 0 & 0 \\
$1997 / 1998$ & 152 & 2 & - & 5 & 6 & 2 & - & - & 1 & 0 & 0 \\
$1998 / 1999$ & 190 & 14 & 14 & 5 & 13 & 3 & 6 & 8 & 3 & 0 & 0 \\
$1999 / 2000$ & 98 & 31 & 41 & 6 & 14 & 2 & 9 & 12 & 4 & 0 & 0 \\
\hline
\end{tabular}

Punto and SI1, which is a new source of resistance (A. Jahoor, personal communication). Some frequencies increased markedly, e.g. virulence matching Steffi, Henni and Goldie. However, Steffi was never grown extensively in Denmark, whereas Henni and Goldie occupied up to $10-15 \%$ of the spring barley area. In 1999, Steffi, Goldie, Meltan and SI1 were also included in the differential sets in France, Slovakia and Latvia. Results for virulence on Steffi, Goldie and Meltan were similar to those observed in Denmark in 1999, but virulence matching SI1 was detected in Slovakia and Latvia.

The Mlo resistance constitutes a particular case. It is based on a single recessive allele among several known mlo-alleles (see Lyngkaer et al., this volume). Although Mlo-resistant varieties have been grown since 1979, only low levels of infection are occasionally seen on these varieties. Such sporadic infections reflect traits of the different types of host cells, and not a genetic change in the pathogen population [27, 32, 42].

In the national survey programmes, most laboratories have included $M l o$-resistant varieties in their differential sets. In these sets, Mlo-resistant Apex sometimes exhibited infection, but the reactions were generally not repeatable, suggesting that slightly variable test conditions were the cause of the sporadic infections seen in some standard survey tests [45]. In Denmark, increased Mlo-aggressiveness has not been detected in the aerial mildew populations. The Danish investigations were based on the number of colonies on trap plants of Apex and Alexis, and generally accounted for less than $1 \%$ of those collected on variety Igri, which possesses Mlra being matched by more than $99 \%$ of the Danish barley powdery mildew population. Between 1993 and 1997, approximately 100 isolates were analysed by the technique developed by Lyngkjær et al. [33], and in these tests no isolates with increased virulence were found.

A comprehensive survey was carried out in GB in 1998 and 1999 (Tab. IV). Isolates of three different origins were investigated: (1) isolates collected from Mlo-resistant varieties, (2) isolates from random spore samples giving rise to more mildew than expected on the Mlo differentials Apex and Riviera (denoted Apex+), and (3) isolates from the same source as (2) but showing no infections on Apex or Riviera in the original tests (denoted Apex0). Specific isolates were tested in both years, and repeated up to four times. Actual infection levels varied between tests and years, but the ranking of varieties remained the same. In general, Apex+ isolates gave the highest infection levels in all tests, but in one of the four tests, the isolates collected on Mlo-resistant varieties gave highest infection (details not shown). The lowest amount of infection was given by isolates designated Apex0, i.e. isolates that in the initial survey tests showed no infection on Apex or Riviera. All the Mlo-resistant varieties grown remained highly resistant under field conditions.

A survey carried out in Germany, Czech Republic and Slovakia in 1997 resulted in a few isolates denoted 'partially Mlo-virulent', i.e. isolates that gave at least five times higher infection efficiency than 'wild-types' and were self-sustainable on the Mlo-resistant host [42]. None of the isolates tested was as aggressive as isolate HL-3, developed in a selection-mutation experiment by 
Table IV. Percent powdery mildew infection, relative to Golden Promise (susceptible standard) on varieties carrying mlo-resistance. Summary based on Slater and Clarkson [45, 46].

\begin{tabular}{lcccccccc}
\hline Isolate designation & Year collected & Year tested & No isolates & Chariot & Landlord & Riviera & Chalice & Apex \\
\hline Apex0 & 1970 & 1999 & 1 & 0 & 0 & 0 & 0 & 0 \\
Apex0 & 1998 & 1998 & 15 & 0.8 & 0.1 & 0.6 & 6.8 & 2.2 \\
Apex0 & 1998 & 1999 & $2^{\mathrm{a}}$ & 0 & 0 & 0 & 1.3 & 0 \\
Apex+ & 1998 & 1998 & 14 & 3.0 & 0.4 & 1.7 & 10.2 & 2.2 \\
Apex+ & 1998 & 1999 & $5^{\mathrm{b}}$ & 5.0 & 0.8 & 6.0 & 12.0 & 8.5 \\
Apex+ & 1999 & 1999 & 12 & 1.9 & 0.3 & 2.2 & 5.3 & 4.5 \\
Mlo & 1998 & 1998 & 7 & 3.5 & 0.6 & 1.9 & 11.3 & 3.6 \\
\hline
\end{tabular}

a Isolates chosen among the 15 tested in 1998.

${ }^{\mathrm{b}}$ Isolates chosen among the 14 tested in 1998.

Schwarzbach [42]. HL-3 is one of two known and intensively studied 'Mlo-virulent' isolates; the other (designated 'Race I') was collected in Japan in the late 1950s [33]. See also the paper by Lyngkjær et al. in this volume.

It is thus possible, that some selection in favour of increased growth on Mlo-resistant varieties has taken place in the barley powdery mildew population in Britain and elsewhere in Europe.

\subsubsection{Virulence dynamics in Europe}

Between 20 and 767 single colonies of barley powdery mildew were tested annually in each country. A set of 9 differential lines was included in most countries to compare virulence frequencies on a European scale [2]. In general, the nine virulence frequencies were intermediate to high, thereby having only a minor effect in controlling powdery mildew in Europe (Fig. 1). This was the case for all regions and years, except the frequencies of $V a 3$ in the British Isles and France, where varieties with the matching resistance gene were not grown. However, the virulence was also present in these areas, and if varieties with Mla3 resistance were introduced, this resistance would probably be overcome within a short time. Frequencies of $\mathrm{Va}, \mathrm{Va} 9$, $V a 12, V k$ and $V L a$ in many cases were higher than $50 \%$, which can be explained by a frequent use of the matching resistance genes. From 1995 to 1999, the main changes concerned Val (increase in GB, FR, LV, DK, FI, AT, HU), Val3 (decrease in GB, $\mathrm{FR}, \mathrm{DK}$, increase in $\mathrm{CZ}$ ), and $V L a$ (increase in GB,
NI, FR, DK, FI, CZ). Other virulences that were only analysed in some countries had intermediate to high frequencies, e.g. ValO, Va22, Vg, Vh, Vat, V1192, VCP, VAb.

Most of the barley varieties used in Europe possess more than one powdery mildew resistance gene $[7,8,10,12]$. In survey programmes that aim to predict the effect of powdery mildew resistance in commercial varieties, and to give advice for breeders and farmers, it is therefore important to provide frequencies of virulence gene combinations. In many cases, such frequencies deviate from the product of the single gene frequencies due to gametic disequilibria (syn. linkage disequilibria or non-random associations) in the barley powdery mildew population [e.g. 20, 51].

In the Danish survey, a number of variety groups were defined according to the presence of resistance genes and combinations thereof (Tab. V). In general, the virulence frequencies matching single resistance genes remained intermediate to high between 1996 and 1999, and so did the combinations (Tab. VI). At present, the powdery mildew resistances of these varieties are therefore unlikely to provide sufficient powdery mildew control in years with favourable conditions for disease development. However, in years prior to 1996 , several resistance gene combinations were effective in controlling mildew under field conditions, while the genes singly gave insufficient control (data not shown). 


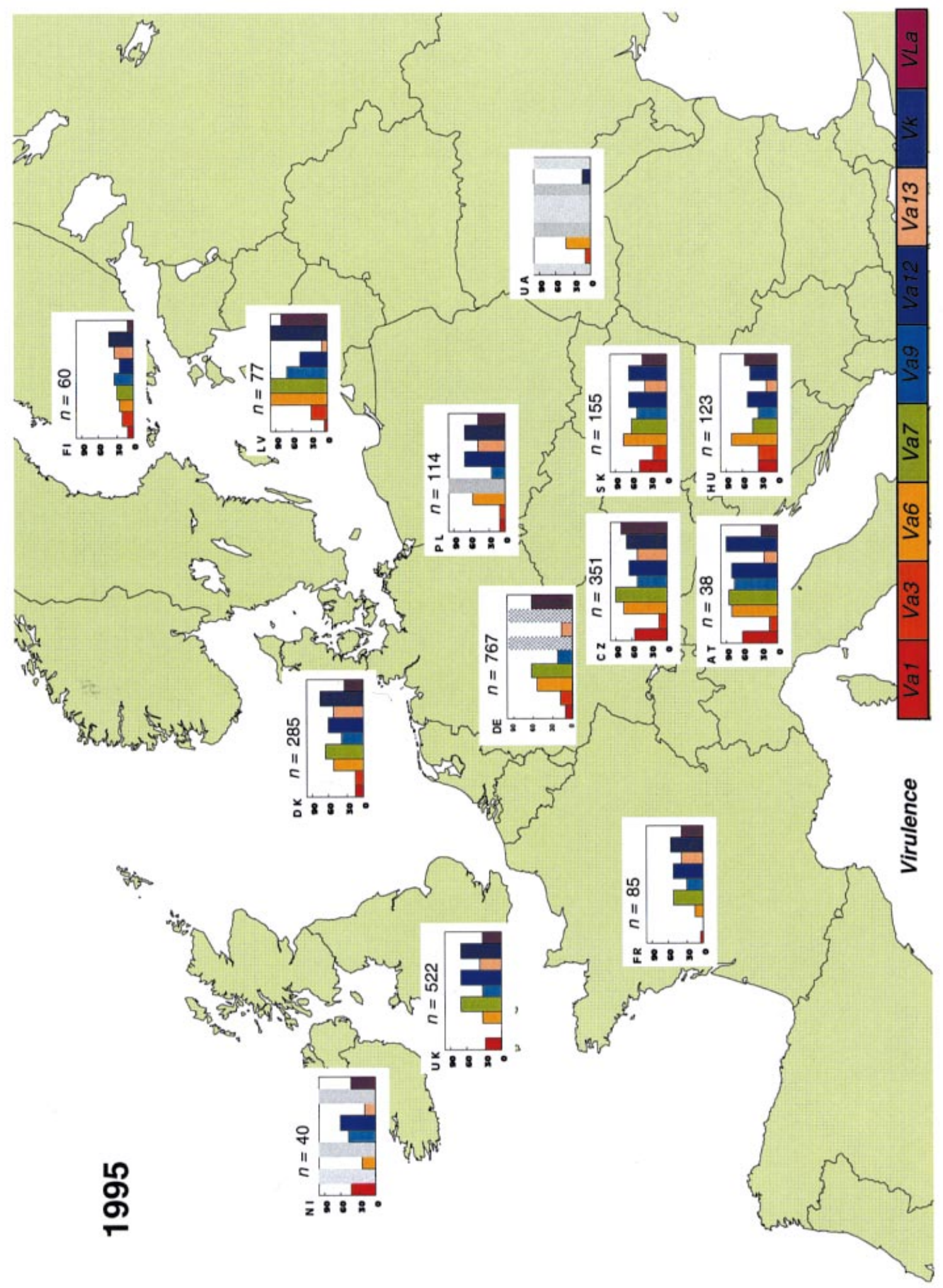




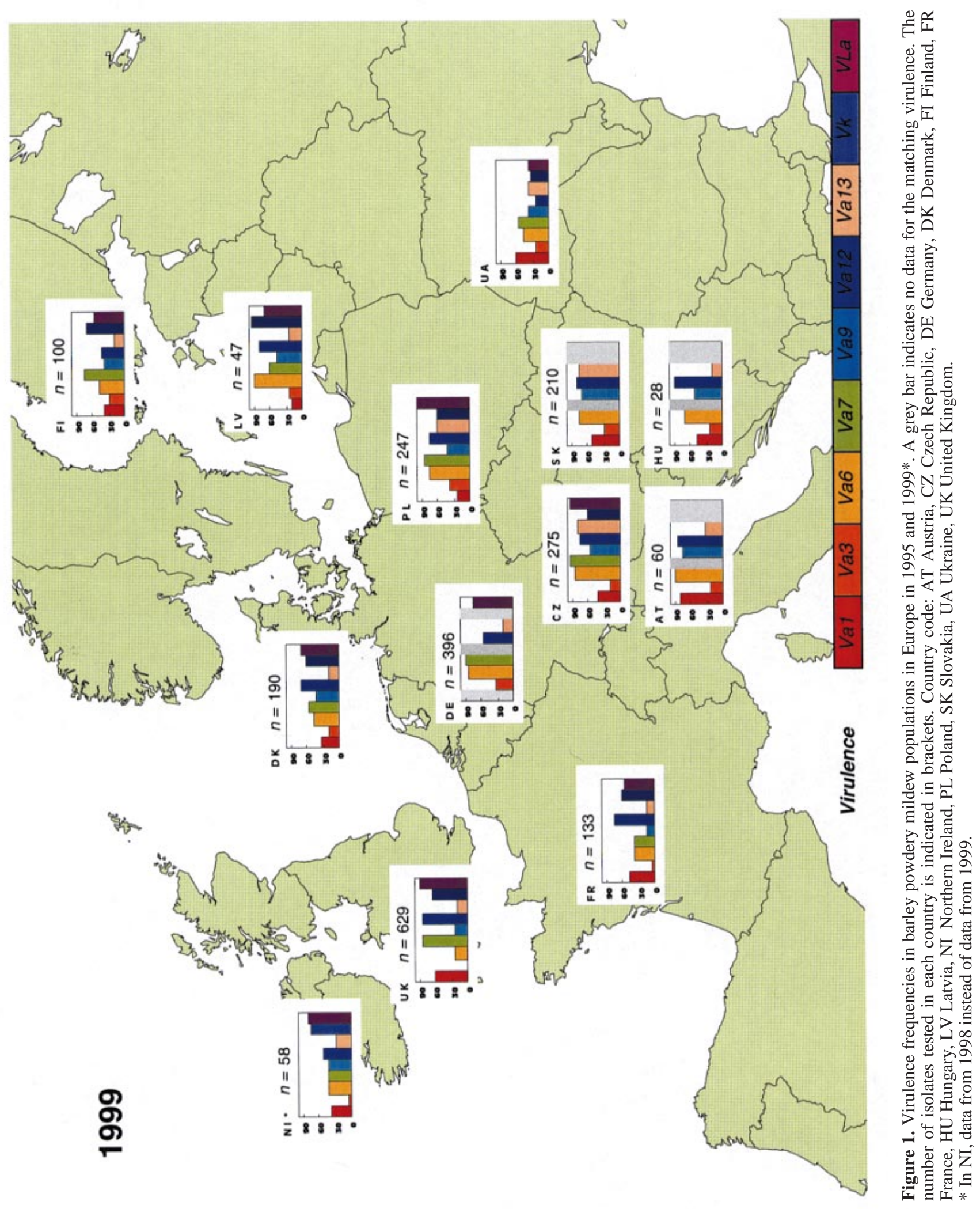


Table V. Danish grown spring barley varieties and their powdery mildew resistance.

\begin{tabular}{llll}
\hline 1. & Mla7+Mlk, Mla7 & $:$ & Limbo, Sultane, Tilda \\
2. & Mla12+Mlg, Mla12 & $:$ & Ballarina, Caminant, Maud \\
3. & Mla7+Mlk+MlLa+Mlg, Mla7+MlLa & $:$ & Canut, Escort \\
4. & Mla12+MlAb+MlLa+Mlg, Mla12+Mlab & $:$ & Optic, Blenheim \\
5. & Mla13+Mlk+Mlg, Mla13 & $:$ & Caruso, Collie, Digger, Senor \\
6. & Mla3 & $:$ & Shamu, Baronesse \\
7. & Mla13+MlLa, Mla13+MlAb, Mla13+MlLa+Mlg & $:$ & Etna, Evelyn, Lysimax \\
8. & Mla1 + MlLa, MLa1 + MlAb, Mla1 & $:$ & Cooper, Cork, Texane \\
\hline
\end{tabular}

Table VI. Summary of virulence frequencies in Denmark from autumn 1996 to autumn 1999, shown as intervals corresponding to highest and lowest frequency, respectively, within groups (cf. Tab. V).

\begin{tabular}{|c|c|c|c|c|c|c|c|c|c|}
\hline \multirow[t]{2}{*}{ Year } & \multirow[t]{2}{*}{ Number of isolates } & \multicolumn{8}{|c|}{ Resistance group } \\
\hline & & 1 & 2 & 3 & 4 & 5 & 6 & 7 & 8 \\
\hline 1996/1997 & 168 & $55-83$ & $63-70$ & $29-42$ & $9-31$ & $24-41$ & 28 & $16-20$ & $11-29$ \\
\hline 1997/1998 & 152 & $48-77$ & $63-74$ & $22-43$ & $12-24$ & $17-33$ & 33 & $13-17$ & $6-22$ \\
\hline 1998/1999 & 190 & $41-59$ & $71-73$ & $31-45$ & $42-57$ & $15-21$ & 17 & $12-15$ & $29-33$ \\
\hline $1999 / 2000$ & 98 & $35-69$ & $53-55$ & $19-41$ & $15-32$ & $11-21$ & 34 & $8-14$ & $9-17$ \\
\hline
\end{tabular}

\subsubsection{Distribution of results}

To the extent that survey data aim at giving advice to farmers and plant breeders, it is essential that the information is distributed efficiently and as soon as possible after the tests have been made. In many cases, results may be distributed to end users informally at meetings and through personal contacts, or they are published in annual reports [e.g. 34, 45]. In Denmark, results have been published through 'Planteinfo' which can be accessed through the Internet (http://www.planteinfo.dk). Booklets, which include results from variety trials, are published in October-November shortly after the growing season [19]. Weekly farming newspapers and magazines also display relevant data. 'PCPlant Protection', a PC-based decision support system [43], is another important channel through which results are transmitted to farmers and advisors. Survey data are utilised in a similar manner in other European countries [29].

\subsection{Field nurseries}

A multinational disease nursery aimed at identifying useful sources of resistance was carried out in 1998 and 1999. The highest levels of powdery mildew resistance were observed for the genotypes Hadm15458-96, Hadm15262-96 and Ivana, with disease scorings close to zero across all environments (Tab. VII). However, recent studies suggest that Ivana (in Germany named Eunova) possess mlo-resistance. The resistance of the two varieties from Hadmersleben was not expressed in associated chlorosis or necrosisis, and may be based on effective, single resistance genes rather than partial resistance. However, in the absence of isolates with matching virulence, it may not be possible to draw conclusions about the genetic basis for these resistances.

There were considerable differences in climatic conditions between locations and years. The majority of the genotypes had a strong interaction with environment, except varieties Arve and Tyra, which were highly susceptible at all sites in both years. The phenotypic expression of resistance in Ohara, Optic, Cooper P 3645 C; Prosa, Hanka, Thule, Inari, Viivi, Bor88369 and Bor88377 changed according to location, even within the same country. The Pallas near-isogenic lines sown 


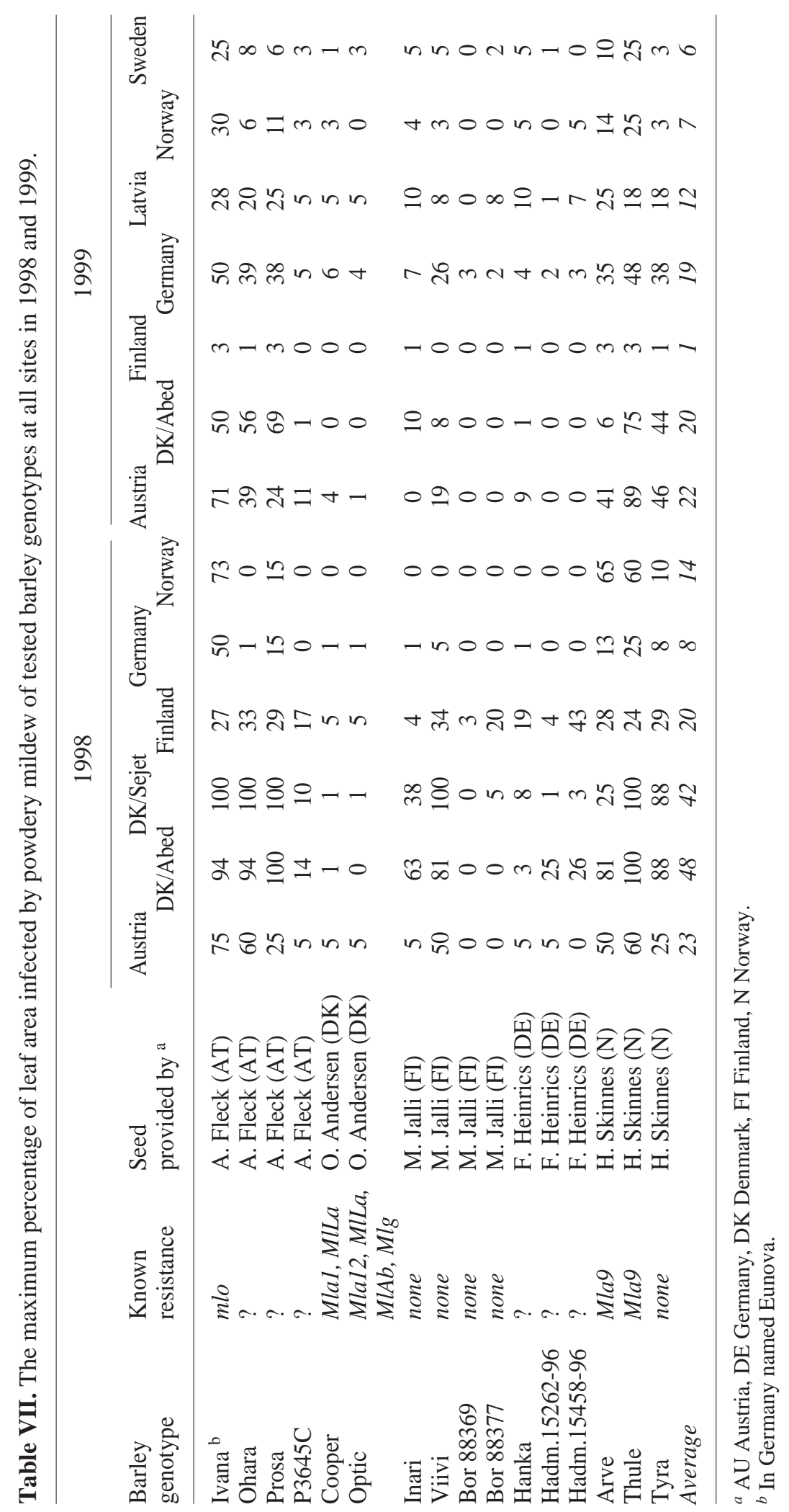


in 1999 in Austria, Denmark, Finland and Sweden clearly indicated that the level of infection was much lower in the northern than in the central part of Europe, and that the composition of the pathogen population was very different (data not shown). The main value of this type of multi-location test is to get information about 'stability' of resistance across different environments including the effect of different pathogen populations. Decisions on the type of the resistance (single- or multi-gene) to investigate would require closer studies of the infection process.

\section{Conclusions and the way ahead}

Besides an efficient dissemination of results, it is currently important to focus on the detection of virulence matching the new sources of resistance being introduced into the barley germplasm. Annual assessments of virulences already present in high frequencies in most parts of Europe may be less important in the future. As the mlo alleles are so widely used in Europe, a survey for the potential development of increased aggressiveness on Mloresistant varieties should have high priority. Continued exchange of ideas, methodology and material (e.g. differential varieties representing new sources of resistance) and rapid distribution of results across national boundaries, as carried out through COST817, is absolutely vital. It is also important to make a link between the national survey programmes and multinational survey activities (e.g. [13, 30, 31]).

The use of survey data to draw conclusions about general population genetic aspects of the barley powdery mildew pathogen should proceed with caution because many important evolutionary forces are often not known [38, 51]. Selection due to host resistance genes is one powerful force which strongly influences the composition of the population $[4,9,21]$, but which may give rise to patterns that easily can be misinterpreted, e.g. gametic disequilibrium. Examples of how gametic disequilibrium and subsequent hitch-hiking effects may give rise to misleading interpretation of changes in unnecessary virulence alleles and com- plexity of pathotypes have been given elsewhere [23]. Time of sampling, knowledge of likely source varieties for the spores/isolates collected, the possibilities and limitations given by the differential varieties used, and the theoretical consequences thereof, are other important aspects which should be kept in mind before genetic conclusions are drawn on the basis of survey data.

Acknowledgements: The authors are grateful for the invaluable contributions made by all other COST817 members of the barley powdery mildew sub-group for virulence surveys and the working group for partial resistance: I. Araja, R. Bilinski, L. Bousset, H.J. Czembor, J.D.S. Clarkson, K. Flath, J. Fuchs, E. Gacek, G. Kosilovich, I. Kokina, E. Krippel, M. Lyngkjær, L. Munk, H. Østergård, M. Rasmussen, A. Ruddock, M. Sykora, R. Zederbauer, B. Schwatz. All the participants wish to thank COST817 for supporting travel expenses that were necessary for meeting and to carry out short-term scientific missions. These activities allowed people to interact and discuss scientific matters across national borders, and altogether they contributed to the success of the action. J. Fuchs and E. Limpert are grateful for additional support from COST Switzerland.

\section{Appendix}

Ole Andersen: Sejet Plant Breeding Station, 8700 Horsens, Denmark

Gottfried BESENHOFER: Bundesamt und Forschungszentrum fuer Landwirtschaft, Spargelfeldstrasse 191, PO Box 400, 1226 Vienna, Austria

Jerzy H. CZEMBoR: Plant Breeding and Acclimatization Institute, IHAR, Department of Genetics and Plant Breeding, 05-870 Blonie, Radzikow, Poland

Antonin DREISEITL: Agricultural Research Institute, Havlickova 2787, PO Box 55, 76741 Kromeriz, Czech Republic

Friedrich Felsenstein: EpiGene GmbH Biotechnology in Plant Protection, Hohenbachernstrasse 19-21, 85354 Freising, Germany

Andreas FlECK: Probstdorfer Saatzucht, Saatzuchtstrase 11, 2301 Gross Enzersdorf, Austria

Fritz HeINRICS: Saatzucht Hadmersleben, Kroppenstedter Strasse, 39398 Hadmersleben, Germany

Rickard Jonsson: Cereal Breeding Dept., Svalöf Weibull AB, 26881 Svalöv, Sweden 
Eckhard LIMPERT: ETH Zentrum/LFW, Phytomedizin/Pathologie, Universitätsstrasse 2, 8092 Zürich, Switzerland

Peter Mercer: Plant Pathology Research Division, Dept. Agriculture and Rural Development, Northern Ireland, Newforge Lane, Belfast BT9 5PX, UK

Svetozar PlesNiK: Comenius University, Faculty of Natural Sciences, Mlynska Dolina B-1, 84215 Bratislava, Slovakia

Isaak RASHAL: Institute of Biology of the University of Latvia, Plant Genetics Laboratory, Salaspils, 2169, Latvia

Helge SKINNES: Department of Horticulture and Crop Sci., PO Box 5022, 1432 Aas, Norway

Susan SLATER: National Institute of Agricultural Botany, Cambridge, CB3 OLE, UK

Olga Vronska: Ukrain. Acad. Agr. Sci., Institute of Agriculture, Obroshino, Lviv Province, 292084, Ukraine

\section{References}

[1] Andrivon D., de Vallavieille-Pope C., Racial diversity and complexity in regional populations of Erysiphe graminis f. sp. hordei in France over a 5-year period, Plant Pathol. 42 (1993) 443-464.

[2] Bayles R.M., Report of European Cereal Pathogen Virulence Surveys for 1995 and 1996, Cereal Rusts and Powdery Mildew Bull. 25 (1998) 1-28.

[3] Boesen B., Hovmøller M.S., Jørgensen J.H., Designation of barley and wheat powdery mildew resistance and virulence in Europe, in: Limpert E., Finckh M.R., Wolfe M.S. (Eds.), Cost 817, Integrated control of cereal mildew and rust: towards coordination of research across Europe, ECSC-EC-EAEC, Brussels, Belgium, 1996, pp. 2-9.

[4] Brown J.K.M., Chance and selection in the evolution of barley mildew, Trends in Microbiol. 2 (1994) 470-475.

[5] Brown J.K.M., Pathogens' responses to the management of disease resistance genes, Adv. in Plant Pathol. 11 (1995) 75-102.

[6] Brown J.K.M., Wolfe M.S., Structure and evolution of a population of Erysiphe graminis f. sp. hordei, Plant Pathol. 39 (1990) 376-390.

[7] Brown J.K.M., Jørgensen J.H., A catalogue of mildew resistance genes in European barley varieties, in: Jørgensen J.H. (Ed.), Integrated control of cereal mildews: virulence patterns and their changes, Ris $\varnothing$
National Laboratory, Roskilde, Denmark, 1991, pp. 263-286.

[8] Caffier V., de Vallavieille-Pope C., Regional distribution of resistances to powdery mildew in winter and spring cultivars in the northern part of France, Plant Breed. 115 (1996) 94-100.

[9] Caffier V., Hoffstadt T., Leconte M., de Vallavieille-Pope C., Seasonal changes in pathotype complexity in French populations of barley powdery mildew, Plant Pathol. 45 (1996) 454-468.

[10] Czembor J.H., Czembor H.J., Powdery mildew resistance in cultivars of spring barley from Polish register, Plant Breed. Seed Sci. 42 (1998) 87-99.

[11] Dreiseitl A., Comparison of methods to study powdery mildew and monitor the population of Erysiphe graminis f. sp. hordei in 1997, Plant Prot. Sci. 34 (1998) 33-38.

[12] Dreiseitl A., Jørgensen J.H., Powdery mildew resistance in Czech and Slovak barley cultivars, Plant Breed. 119 (2000) 203-209.

[13] Felsenstein F., Virulenz und Fungizidsensitivität des Weizenmehltaus, Erysiphe graminis DC. f. sp. tritici Marchal, in Europe, Technische Universität München, Germany, Ph.D. thesis, 1991, 179 p.

[14] Gacek E.S., Czembor H.J., Bilinski Z.R., Population structure of barley powdery mildew in Poland, Proceedings of the 9th Cereal Rust and Powdery Mildew Conference, Lunteren, 1996, pp. 272-274.

[15] Heitefuss R., Ebrahim-Nesbat F., Ordonez M.T., Schorn-Kasten K., Investigations on adult plant resistance of barley against Erysiphe graminis f. sp. hordei, J. Phytopathol. 145 (1997) 177-184.

[16] Hermansen J.E., Stix E., Evidence of wind dispersal of powdery mildew conidia across the North Sea, Royal Veterinary and Agricultural University Yearbook 1974, Copenhagen, 1974, pp. 87-100.

[17] Honecker L., Weitere Mitteilungen über das Vorkommen biologischer Rassen des Gersten Meltaues (Erysiphe graminis hordei Marchal), ihre Verbreitung in Deutschland und die sich daraus ergebenden Richtlinien für die Immunitätszüchtung, Der Züchter (1935) 113-119.

[18] Hovmøller M.S., Survey activities for fungal pathogens on cereals in Denmark, Czech J. Genet. Plant Breed. 34 (1998), 107-109.

[19] Hovmøller M.S., Virulensundersøgelser i bygog hvedemeldug 1996-99, in: Deneken G., Pedersen J.B. (Eds.), 'Sortsfors $\emptyset$ g 1999', Danmarks Jordbrugs- 
forskning and Landskontoret for Planteavl, 1999, pp. 6-8.

[20] Hovmøller M.S., Østergård H., Gametic disequilibria between virulence genes in barley powdery mildew populations in relation to selection and recombination, II: Danish observations, Plant Pathol. 40 (1991) 178-189.

[21] Hovmøller M.S., Munk L., Østergård H., Observed and predicted virulence gene frequencies at 11 loci in a local barley powdery mildew population, Phytopathology 83 (1993) 253-260.

[22] Hovmøller M.S., Munk L., Østergård H., Comparison of mobile and stationary spore-sampling techniques for estimating virulence frequencies in aerial barley powdery mildew populations, Plant Pathol. 44 (1995) 829-837.

[23] Hovmøller M.S., Østergård H., Munk L., Modelling Virulence Dynamics of Airborne Plant Pathogens in Relation to Selection by Host Resistance in Agricultural Crops, in: Cruite I.R., Holub E.B., Burdon J.J. (Eds.), The Gene-for-Gene Relationship in Plant-Parasite Interactions, CAB International, 1997, pp. 173-190.

[24] Huszar J., Sykora M., Plesnik S., Vanco B., Krippel E., Reaction of various barley genotypes on infection, frequency and genes complexicity of Erysiphe graminis DC. f. sp. hordei in Slovakia, J. Plant Dis. Prot. 103 (1996) 596-601.

[25] Jahoor A., Fischbeck G., Sources of resistance to powdery mildew in barley lines derived from Hordeum spontaneum collected in Israel, Plant Breed. 99 (1987) 274-281.

[26] Jørgensen J.H., Durability of resistance in the pathosystem: barley - powdery mildew, in: Durability of Disease Resistance, Proceedings of a Symposium, Wageningen, The Netherlands, 1992, pp. 159-176.

[27] Jørgensen J.H., Genetics of Powdery Mildew Resistance in Barley, Crit. Rev. Plant Sci. 13 (1994) 97-119.

[28] Kølster P., Munk L., Stølen O., Løhde J., Near-isogenic barley lines with genes for resistance to powdery mildew, Crop Sci. 26 (1986) 903-907.

[29] Limpert E., Bartoš P., Analysis of pathogen virulence as decision support for breeding and cultivar choice, in: Hartleb H., Heitefuss H., Hoppe H.H. (Eds.), Resistance of crop plants against fungi, Fischer, Jena, 1997, pp. 401-424.

[30] Limpert E., Andrivon D., Fischbeck G., Virulence patterns in populations of Erysiphe graminis f. sp. hordei in Europe in 1986, Plant Pathol. 39 (1990) 402-415.

[31] Limpert E., Godet F., Müller K., Dispersal of cereal mildews across Europe, Agric. For. Meteorol. 97 (1999) 293-308.

[32] Lyngkjær M.F., Østergård H., Interaction between powdery mildew and barley with mlo5 mildew resistance, Plant Pathol. 47 (1998) 252-258.

[33] Lyngkjær M.F., Jensen H.P., Østergård H., A Japanese mildew isolate with exceptionally large infection efficiency on Mlo-resistant barley, Plant Pathol. 44 (1995) 786-790.

[34] Mercer P., Mildew of barley in Northern Ireland, U.K. Cereal Pathogen Virulence Survey 1995, Ann. Rep. (1996) 44-46.

[35] Moseman J.G., Macer R.C.F., Greeley L.W., Genetic studies with cultures of Erysiphe graminis f. sp. hordei virulent on Hordeum spontaneum, Trans. Br. Mycol. Soc. 48 (1965) 479-489.

[36] Newton A.C., Dashwood E.P., The interaction of humidity and resistance elicitors on expression of polygenic resistance of barley to mildew. Phytopath. Z. 146 (1998) 123-130.

[37] Nover I., Sechjährige Beobachtungen über die physiologische Spezialisierung des echten Mehltaus (Erysiphe graminis DC) von Weizen und Gerste in Deutchland, Phytopathol. Z. 31 (1958) 85-107.

[38] Østergård H., Hovmøller M.S., Gametic disequilibria between virulence genes in barley powdery mildew populations in relation to selection and recombination, I. Models, Plant Pathol. 40 (1991) 166-177.

[39] Parlevliet J.E., Zadoks, J.C., The integrated concept of disease resistance: a new view including horizontal and vertical resistance in plants, Euphytica 26 (1977) 5-21.

[40] Rashal I., Tueryapina R., Barley powdery mildew in Latvia: Genetic structure of the pathogen population, in: Limpert E., Finckh M.R., Wolfe M.S. (Eds.), Cost 817, Integrated control of cereal mildew and rust: towards coordination of research across Europe, ECSC-EC-EAEC, Brussels, Belgium, 1996, pp. 15-19.

[41] Schwarzbach E., A high throughput jet trap for collecting mildew spores on living leaves, Phytopathol. Z. 94 (1979) 165-171.

[42] Schwarzbach E., The mlo based resistance of barley to mildew and the response of mildew populations to the use of varieties with the mlo gene, Czech J. Genet. Plant Breed. 34 (1998) 3-10. 
[43] Secher B.J.M., Jørgensen L.N., Murali N.S., Boll P., Field validation of a decision support system for the control of pests and diseases in cereals in Denmark, Pest. Sci. 45 (1995) 195-199.

[44] Segal A., Dörr K.H., Fischbeck G., Zohary D., Wahl I., Genotypic composition and mildew resistance in a natural population of wild barley, Hordeum Spontaneum, Plant Breed. 99 (1987) 118-127.

[45] Slater S.E., Clarkson J.D.S., Mildew of barley, UK Cereal Pathogen Virulence Survey 1998, Ann. Rep. (1999) 43-51.

[46] Slater S.E., Clarkson J.D.S., Mildew of barley, UK Cereal Pathogen Virulence Survey 1999, Ann. Rep. (2000) 48-56.

[47] Sykora M., Krippel E., Virulence frequencies in the barley powdery mildew (Erysiphe graminis f. sp. hordei) population in middle Europe, Cereal Rust and Powdery Mildews Bull. 22 (1994) 25-31.

[48] Vronska O., Kosilovich G., Kopchi Z., Maruhnyak A., Effectiveness of host resistance to the barley powdery mildew population in western Ukraine, in: Limpert E., Finckh M.R., Wolfe M.S. (Eds.), Cost 817, Integrated control of cereal mildew and rust: Towards coordination of research across Europe, ECSC-EC-EAEC, Brussels, Belgium, 1996, pp. 73-78.

[49] Wolfe M.S., Mildew- barley. Physiologic race surveys 1967, Annual report from the Physiologic Race Survey Committee, National Institute of Agricultural Botany, Cambridge, UK, 1967, pp. 27-31.

[50] Wolfe M.S., Trying to understand and control powdery mildew, Plant Pathol. 33 (1984) 451-466.

[51] Wolfe M.S., Knott D.R., Populations of plant pathogens: Some constraints on analysis of variation in pathogenicity, Plant Pathol. 31 (1982) 79-90.

[52] Wolfe M.S., McDermott J.M., Population genetics of plant pathogen interactions: the example of the Erysiphe graminis - Hordeum vulgare pathosystem, Ann. Rev. Phytopathol. 32 (1994) 89-113.

[53] Wolfe M.S., Schwarzbach E., The use of virulence analysis in cereal mildews, Phytopathol. Z. 82 (1975) 297-302. 